\title{
Mind the weather: a report on inter-annual variations in entomological data within a rural community under insecticide-treated wall lining installation in Kwara State, Nigeria
}

Abiodun Obembe ${ }^{1,2,3^{*}}$, Kehinde O. K. Popoola ${ }^{2}$, Adedayo O. Oduola ${ }^{4}$ and Samson T. Awolola ${ }^{3}$

\begin{abstract}
Background: Entomological indices within a specific area vary with climatic factors such as rainfall, temperature and relative humidity. Contributions of such weather parameter fluctuations to the changes in entomological data obtained within a community under implementation of a promising vector control intervention should be taken into account. This study reports on inter-annual changes in entomological indices within two rural communities, one of which was under insecticide-treated durable wall lining $(D L)$ installation.
\end{abstract}

Methods: Community-wide DL installation was followed by monthly meteorological data and pyrethrum spray mosquito collections for 2 years in intervention and a similar neighbouring community (control). Human blood meal and sporozoite ELISA tests were conducted on female mosquitoes collected alongside PCR identification of subsamples. Mosquitoes collected at the intervention site were tested in cone susceptibility assays against subsamples of installed DL materials collected on a 6-monthly basis for 2 years. Deltamethrin susceptibility of Anopheles mosquitoes from the intervention site was determined before and after DL installation. Entomological indices in the first and second years were compared within each site.

(Continued on next page)

\footnotetext{
* Correspondence: abiodunobembe@yahoo.com;

abiodun.obembe@kwasu.edu.ng

${ }^{1}$ Department of Biosciences and Biotechnology, Kwara State University

Malete, Malete, Nigeria

${ }^{2}$ Department of Zoology, University of Ibadan, Ibadan, Nigeria

Full list of author information is available at the end of the article
}

(c) The Author(s). 2018 Open Access This article is distributed under the terms of the Creative Commons Attribution 4.0 International License (http://creativecommons.org/licenses/by/4.0/), which permits unrestricted use, distribution, and reproduction in any medium, provided you give appropriate credit to the original author(s) and the source, provide a link to the Creative Commons license, and indicate if changes were made. The Creative Commons Public Domain Dedication waiver (http://creativecommons.org/publicdomain/zero/1.0/) applies to the data made available in this article, unless otherwise stated. 
(Continued from previous page)

Results: Rainfall in the study area increased significantly $(t=-3.45, d f=11, P=0.005)$ from first to second year. Correlation between rainfall and Anopheles densities in both sites were significant $(r=0.681, P<0.001)$. Mosquitoes collected at the intervention site were susceptible (100\%) to deltamethrin at baseline but resistant (92\%) in the second year. However, subsamples of installed DL materials remained effective (100\% mortality) against Anopheles mosquitoes from the intervention site throughout the 6-monthly cone assay exposures. Monthly pyrethrum spray collections showed significant increase in Anopheles densities from first to second year in the control (6.36 \pm 1.61 vs $7.83 \pm 2.39 ; t=-3.47, d f=11, P=0.005)$, but not in the intervention $(2.83 \pm 1.86$ vs $4.23 \pm 3.31 ; t=-2.03, d f=11$, $P=0.067)$ community. However, mean annual mosquito man-biting rates increased significantly in both intervention $\left(0.88 \pm 0.18\right.$ vs $\left.1.06 \pm 0.38 ; F_{(1,10)}=9.50, P=0.012\right)$ and control $\left(1.45 \pm 0.31\right.$ vs $\left.1.61 \pm 0.34 ; F_{(1,10)}=10.18, p=0.010\right)$ sites along with increase ( $\geq 1.6$ times) in sporozoite rates within intervention (0-2.13\%) and control (2.56-4.04\%) communities.

Conclusions: The slight increase in vector density, induced by significant increase in rainfall, led to increased sporozoite infection and significantly increased man-biting rates within the intervention site. These reveal the need for incorporation of integrated vector management strategies to complement DL installation especially in regions with high rainfall and mosquito density. Promising vector control tools such as DL should be evaluated on a long-term basis to reveal the possible effect of weather parameters on control performance and also allow for holistic recommendations.

Keywords: Durable wall lining, Malaria vectors, Rainfall variations

\section{Background}

The decline/upsurge of mosquito indices within an area may not be exclusively due to the implementation of community-based vector control tools. Variations in climatic factors such as temperature and rainfall could contribute to changes in entomological indices $[1,2]$. However, climate induced changes in entomological data occur between seasons and over years [3, 4] and may not be evident in the results of short term or single year surveys. Consequently, there is the need to conduct longterm entomological surveys in any area under vector control intervention. Outcomes of such surveys will help to profile the contributions of weather fluctuations to entomological changes obtained after vector control. Performance of a promising vector control tool under different seasons and years will also assist in making robust recommendations for future deployments of the tool. This is particularly important now that the need for improved vector control tools is currently being emphasized to sustain the recent decline in the global malaria burden.

Insecticide-treated durable wall lining (DL) is one of such tools still under discussion within the research community. It is expected to outlast indoor residual spray (IRS) in the same way long-lasting insecticidal net (LLIN) circumvents the need for conventional insecticide-treated net (ITN) retreatment $[5,6]$. The longest community-based assessments of pyrethroid DL focused on product acceptability and bioefficacy with results of little to no decline in DL bioefficacy over a period of 12-15 months [5, 6]. Moreover, none of the previous DL studies [7-9] considering mosquito vector abundance and infectivity rates were conducted for more than a year to account for the contribution of weather fluctuations to the changes in entomological data obtained within the community under intervention. This study gives an account of variations in endophilic Anopheles mosquito vector abundance and infection rates in relation to rainfall within two rural communities, one of which was under village-scale DL installation in Kwara State, Nigeria.

\section{Methods}

\section{Study area and design}

The study was conducted in Kwara State, North Central Nigeria. The State has been classified as derived Savannah, being the transitional zone between the rain forest and arid Sudan Savannah region of Nigeria [10]. The land area covers about $32,500 \mathrm{~km}^{2}$ with a population of over two million people [11] spread across sixteen Local Government Areas. Annual rainfall ranges between 1000-1500 mm and maximum average temperature between $30-35^{\circ} \mathrm{C}$ [12]. Preliminary visits and assessments were conducted to identify isolated but similar rural communities willing to accept village-wide DL installation. This was based on the report showing the preference of rural communities for the use of $\mathrm{DL}$ as against the urban settlements in Nigeria [5]. Akorede $\left(08^{\circ} 40.048 \mathrm{~N}, 004^{\circ} 31.370 \mathrm{E}\right)$ and Lumoh $\left(08^{\circ} 38.001 \mathrm{~N}, 004^{\circ}\right.$ $33.740 \mathrm{E})$ which were the most similar communities identified in terms of number of houses (14 and 12), households (50 and 45), human population (167 and 155) and baseline Anopheles densities (15.30 and 15.10 per room) were selected as intervention and control communities, respectively. Lumoh community was not a full control treatment due to the unavailability and non-installation of untreated DL in the 
village. Therefore, entomological parameters considered in this study were not compared between the intervention and control communities. Rather, this study reports changes in entomological indices within the intervention community over seasons and years as influenced by possible loss of DL insecticidal efficacy, insecticide resistance or variations in rainfall. Since neighbouring locations are influenced by similar exposures such as climate and environment due to close proximities [13], entomological indices were also assessed in a similar neighbouring (control) community to confirm whether any climate-induced changes in vector abundance within the intervention village was occurring in any other village in the area at the time.

Both communities are in Moro Local Government Area of Kwara State. Houses in the communities were of the mud type with no ceilings and window nets leaving unrestricted entry points for mosquitoes. The residents of the rural communities were mostly farmers that contribute largely to the production of staple food brought to modern markets within and outside the State. Preliminary surveys conducted in several rural communities during study site selection in the area showed the absence of LLIN in the homes visited. Specifically, all the households in the intervention and control villages were without LLIN. This study was therefore not conducted under a universal or moderate LLIN coverage setting because of the unavailability of such rural communities.

\section{Insecticide susceptibility tests}

Non-blood-fed 2-3 day-old adult female Anopheles gambiae (s.l.) mosquitoes reared from larval collections at the intervention site were, respectively, exposed before and after DL installation in the second year to test papers containing diagnostic deltamethrin concentrations following standard procedures [14]. Mosquitoes exposed at baseline (100 mosquitoes, 4 replicates) and in the second year (200 mosquitoes, 8 replicates) were transferred into holding tubes, supplied with $10 \%$ sugar solution and monitored for mortality $24 \mathrm{~h}$ after exposure.

\section{Durable lining installation and susceptibility of Anopheles from the intervention site to $\mathrm{DL}$}

The deltamethrin $(4.4 \mathrm{~g} / \mathrm{kg} \pm 15 \%$ a.i. $)$ incorporated DL (100\% polyethylene) was provided by Vestergaard Frandsen (Lausanne, Switzerland) and installed in all available sleeping rooms in the intervention community. The DL materials were measured and cut according to dimensions of the walls in each room and installed with the capped nails supplied with the lining. Wall-linings were fixed starting from the highest part of the wall and stretched until it is made straight with the bottom part that was folded inwards in cases where the walls were low. The installation was conducted in September 2012 after baseline mosquito collections. Only three unavailable households were not covered with DL out of the 50 households in the village. The inhabitants of the uncovered households had moved out of the village with the houses locked before the commencement of the study. Each subsample $(50 \times 50 \mathrm{~cm})$ of already installed DL materials collected from ten randomly selected rooms were tested against 45 non-blood-fed 2-3 day-old female An. gambiae (s.l.) (five samples/cone, 9 replicates/DL), reared from larval collections at the intervention site, to ascertain continued insecticidal efficacy immediately after installation and at 6 months intervals following standard procedures [15]. The bare wall spaces were replaced with new DL materials. Mosquitoes used for the insecticide susceptibility tests and the continued DL efficacy monitoring were collected from the same larval breeding site at the intervention village. Tracking and visual inspection of DL were conducted during monthly evaluations to identify physical damages or outright removal in the intervention village. Apart from dusts gathering on linings, all the wall-installed DL were intact with no evidence of tear all through the 2 years of the study.

\section{Mosquito collection and identification}

Monthly Anopheles mosquito collections were conducted in ten houses in each of the intervention and control communities from October 2012 to September 2014 using Pyrethrum Spray Catch method [16]. One room was chosen per house and the same rooms were sampled throughout the study. The ten rooms were selected based on the willingness of the occupants to allow the use of the rooms throughout the period of the study. The number of persons sleeping in the rooms the night preceding the mosquito collections was also noted for indirect man-biting rates estimations [16-18]. Mosquito samples were preserved on silica for further processing at The Molecular Entomology and Vector Control Research Laboratory of the Nigerian Institute of Medical Research. All samples were identified using morphological keys [19] with subsamples subjected to species-specific PCR [20] and PCR-RFLP [21] assays for sibling species identification.

\section{Detection of human blood and $P$. falciparum sporozoite infection in mosquitoes}

Plasmodium falciparum circumsporozoite ELISA [22] were done on heads-thoraces of all the female Anopheles gambiae (s.l.) mosquito samples collected. Blood-fed mosquitoes were used for human blood meal ELISA [23]. Monoclonal antibodies and positive controls for the sporozoite ELISA were supplied by Centers for Disease Control and Prevention (Atlanta, USA). Human serum and monoclonal antibodies for blood meal ELISA were obtained from Rockland immunochemicals (Gilbertsville, USA) and Kikergaard and Perry Laboratories (Gaithersburg, USA), respectively. 
Table 1 Rainfall recorded in the area during the study period. Square-root transformation formula $X^{1}=\sqrt{X}+0.5$, where $X^{1}$ is the transformed value and $X$ is the actual value

\begin{tabular}{|c|c|c|c|c|}
\hline \multirow[t]{2}{*}{ Period } & \multicolumn{2}{|c|}{ First year } & \multicolumn{2}{|c|}{ Second year } \\
\hline & $\begin{array}{l}\text { Actual } \\
\text { values }\end{array}$ & $\begin{array}{l}\text { Transformed } \\
\text { values }\end{array}$ & $\begin{array}{l}\text { Actual } \\
\text { values }\end{array}$ & $\begin{array}{l}\text { Transformed } \\
\text { values }\end{array}$ \\
\hline \multicolumn{5}{|l|}{ Dry season } \\
\hline October & 153.7 & 12.42 & 308.8 & 17.59 \\
\hline November & 8.7 & 3.03 & 0.0 & 0.71 \\
\hline December & 25.2 & 5.07 & 6.8 & 2.70 \\
\hline January & 4.8 & 2.30 & 9.7 & 3.19 \\
\hline February & 5.5 & 2.45 & 28.6 & 5.39 \\
\hline March & 38.4 & 6.24 & 52.2 & 7.26 \\
\hline Mean \pm SD & & $5.25 \pm 3.84$ & & $6.14 \pm 6.05$ \\
\hline \multicolumn{5}{|l|}{ Wet season } \\
\hline April & 223.4 & 14.96 & 408.8 & 20.23 \\
\hline May & 121.7 & 11.05 & 232.3 & 15.26 \\
\hline June & 148.4 & 12.20 & 305.2 & 17.48 \\
\hline July & 110.6 & 10.54 & 332.3 & 18.24 \\
\hline August & 51.4 & 7.20 & 225.3 & 15.03 \\
\hline September & 266.5 & 16.34 & 511.7 & 22.63 \\
\hline Mean \pm SD & & $12.05 \pm 3.28$ & & $18.15 \pm 2.93$ \\
\hline Annual mean \pm SD & & $8.65 \pm 4.92$ & & $12.14 \pm 7.74$ \\
\hline
\end{tabular}

The difference between first and second year mean rainfall values was significant in the wet $(P<0.001)$ but not in the dry $(P=0.494)$ season. Annual mean rainfall value was significantly $(P=0.005)$ higher in the second year compared to the first year

\section{Collection of rainfall data}

Data on monthly rainfall in the state during the period of the mosquito collection were obtained from the Nigerian Meteorological Agency station at the Ilorin International Airport.

\section{Data analyses}

Anopheles densities were taken as the numbers of female Anopheles gambiae (s.l.) mosquitoes collected from the ten rooms surveyed in each site per unit time. Man-biting rates (MBR) were determined as the number of blood-fed and half-gravid female Anopheles samples collected divided by the number of persons sleeping in the rooms the night preceding the collection multiplied by human blood index [16-18]. Human blood index (HBI) was determined as proportion of blood-fed and half-gravid samples with human blood. The number of people in the rooms was taken as a reflection of human availability for mosquito bites because the persons in both villages were not sleeping under a bednet. Data obtained (Anopheles densities, man-biting rates and rainfall values) were transformed $[\sqrt{ } \mathrm{n}$ +0.5 ] to accommodate zero values and attain normal distribution [24]. Sporozoite infection rates of the indoor resting mosquitoes collected were taken as percentage of female Anopheles found with Plasmodium falciparum circumsporozoite protein. Mean densities of female Anopheles gambiae (s.l.) mosquitoes collected in the first and second years were compared within each site using Student's t-test (SPSS 16 software) to determine the significance $(P<0.05)$ of differences. First and second year mean man-biting rates were also compared within each site using logistic regression. Monthly Anopheles densities

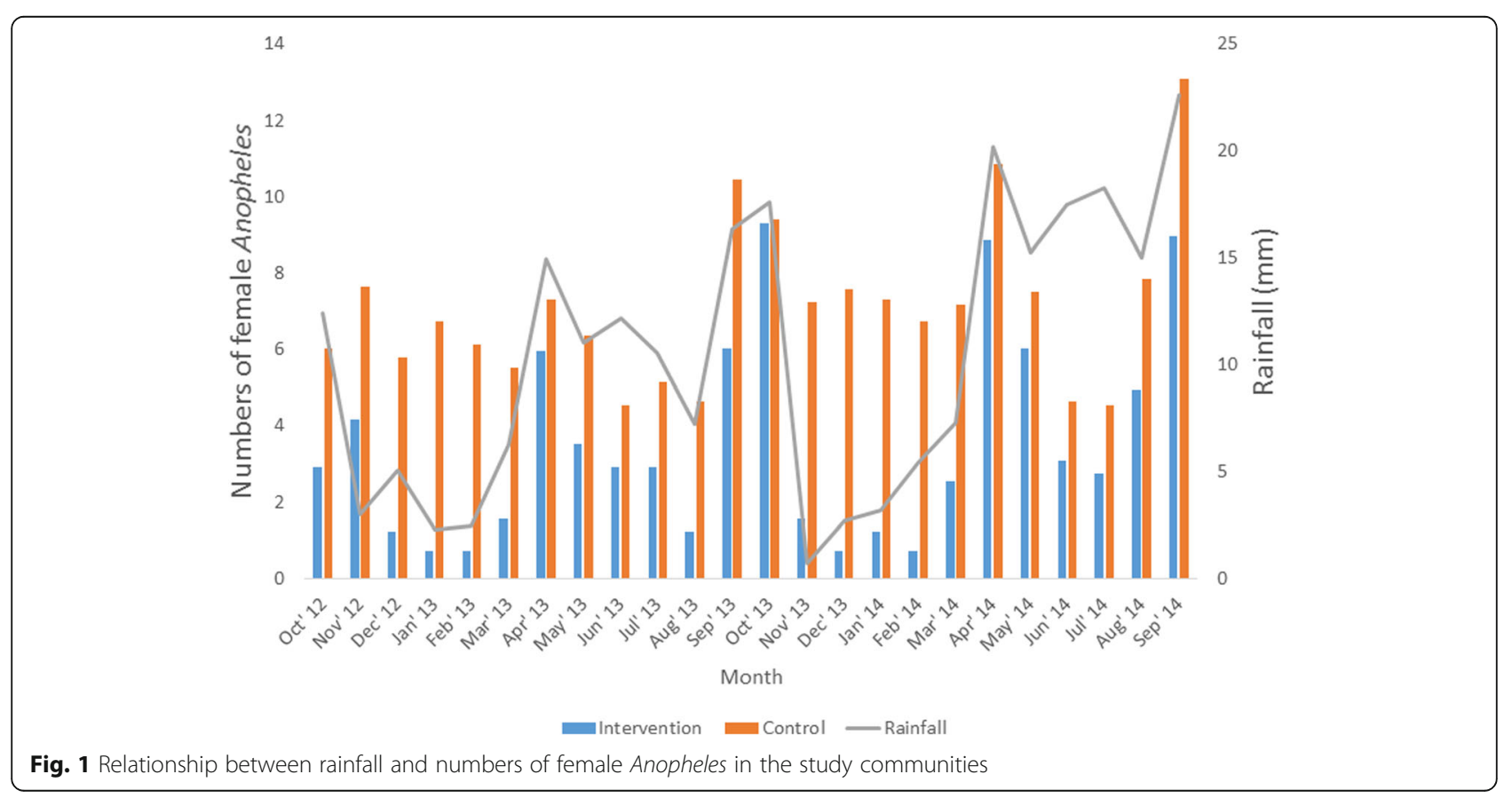


Table 2 Correlation $(r=0.681, P<0.001)$ between rainfall and female Anopheles density in the study area. Square root transformation formula $X^{1}=\sqrt{ } X+0.5$, where $X^{1}$ is the transformed value and $X$ is the actual value

\begin{tabular}{|c|c|c|c|c|c|c|}
\hline \multirow[t]{2}{*}{ Month } & \multicolumn{6}{|l|}{ Anopheles density } \\
\hline & $\begin{array}{l}\text { Actual values in } \\
\text { intervention site }\end{array}$ & $\begin{array}{l}\text { Transformed values in } \\
\text { intervention site }\end{array}$ & $\begin{array}{l}\text { Actual values } \\
\text { in control site }\end{array}$ & $\begin{array}{l}\text { Transformed } \\
\text { values in } \\
\text { control site }\end{array}$ & $\begin{array}{l}\text { Total Anopheles } \\
\text { densities } \\
\text { in both sites }\end{array}$ & $\begin{array}{l}\text { Rainfall } \\
(\mathrm{mm})\end{array}$ \\
\hline \multicolumn{7}{|l|}{ First year } \\
\hline October 2012 & 8 & 2.92 & 36 & 6.04 & 8.96 & 12.42 \\
\hline November 2012 & 17 & 4.18 & 58 & 7.65 & 11.83 & 3.03 \\
\hline December 2012 & 1 & 1.22 & 33 & 5.79 & 7.01 & 5.07 \\
\hline January 2013 & 0 & 0.71 & 45 & 6.75 & 7.46 & 2.30 \\
\hline February 2013 & 0 & 0.71 & 37 & 6.12 & 6.83 & 2.45 \\
\hline March 2013 & 2 & 1.58 & 30 & 5.52 & 7.10 & 6.24 \\
\hline April 2013 & 35 & 5.96 & 53 & 7.31 & 13.27 & 14.96 \\
\hline May 2013 & 12 & 3.54 & 40 & 6.36 & 9.90 & 11.05 \\
\hline June 2013 & 8 & 2.92 & 20 & 4.53 & 7.45 & 12.20 \\
\hline July 2013 & 8 & 2.92 & 26 & 5.15 & 8.07 & 10.54 \\
\hline August 2013 & 1 & 1.22 & 21 & 4.64 & 5.86 & 7.20 \\
\hline September 2013 & 36 & 6.04 & 109 & 10.46 & 16.50 & 16.34 \\
\hline Total & 128 & 33.92 & 508 & 76.32 & 110.24 & 103.80 \\
\hline \multicolumn{7}{|l|}{ Second year } \\
\hline October 2013 & 86 & 9.30 & 88 & 9.41 & 18.71 & 17.59 \\
\hline November 2013 & 2 & 1.58 & 52 & 7.25 & 8.83 & 0.71 \\
\hline December 2013 & 0 & 0.71 & 57 & 7.58 & 8.29 & 2.70 \\
\hline January 2014 & 1 & 1.22 & 53 & 7.31 & 8.53 & 3.19 \\
\hline February 2014 & 0 & 0.71 & 45 & 6.75 & 7.46 & 5.39 \\
\hline March 2014 & 6 & 2.55 & 51 & 7.18 & 9.73 & 7.26 \\
\hline April 2014 & 78 & 8.86 & 117 & 10.84 & 19.70 & 20.23 \\
\hline May 2014 & 36 & 6.04 & 56 & 7.52 & 13.56 & 15.26 \\
\hline June 2014 & 9 & 3.08 & 21 & 4.64 & 7.72 & 17.48 \\
\hline July 2014 & 7 & 2.74 & 20 & 4.53 & 7.27 & 18.24 \\
\hline August 2014 & 24 & 4.95 & 61 & 7.84 & 12.79 & 15.03 \\
\hline September 2014 & 80 & 8.97 & 171 & 13.09 & 22.06 & 22.63 \\
\hline Total & 329 & 50.71 & 792 & 93.94 & 144.65 & 145.71 \\
\hline
\end{tabular}

for both sites were pooled and correlated (Pearson's correlation) with monthly rainfall values obtained for the state during the study period. Rainfall measurements were not taken in the study communities but the Average State Rainfall is believed to reflect the general trend of rainfall in the study villages.

\section{Results}

\section{Rainfall and Anopheles densities}

Wet season $(t=-10.29, d f=5, P<0.001)$ and annual $(t=-3.45, d f=11, P=0.005)$ mean rainfall were significantly higher in the second year compared to first year (Table 1). Highest numbers of mosquitoes occurred during highest rainfall (April, September and October) period except for June and July (Fig. 1). Significant correlation $(r=0.681, P<0.001)$ was found between rainfall and Anopheles densities in the study area. (Table 2). Mean densities of Anopheles collected were significantly higher in the second year than the first year in the control (6.36 \pm 1.61 vs $7.83 \pm 2.39 ; t=-3.47, d f=11, P=0.005$ ) but not in the intervention site $(2.83 \pm 1.86$ vs $4.23 \pm 3.31 ; t=-2.03$, $d f=11, P=0.067)($ Fig. 2).

\section{Man-biting and sporozoite infection rates of indoor resting female Anopheles}

Monthly man-biting rates (Additional file 1: Table S1) derived from Anopheles mosquito human blood index (Additional file 2: Table S2) were mostly higher in the first 


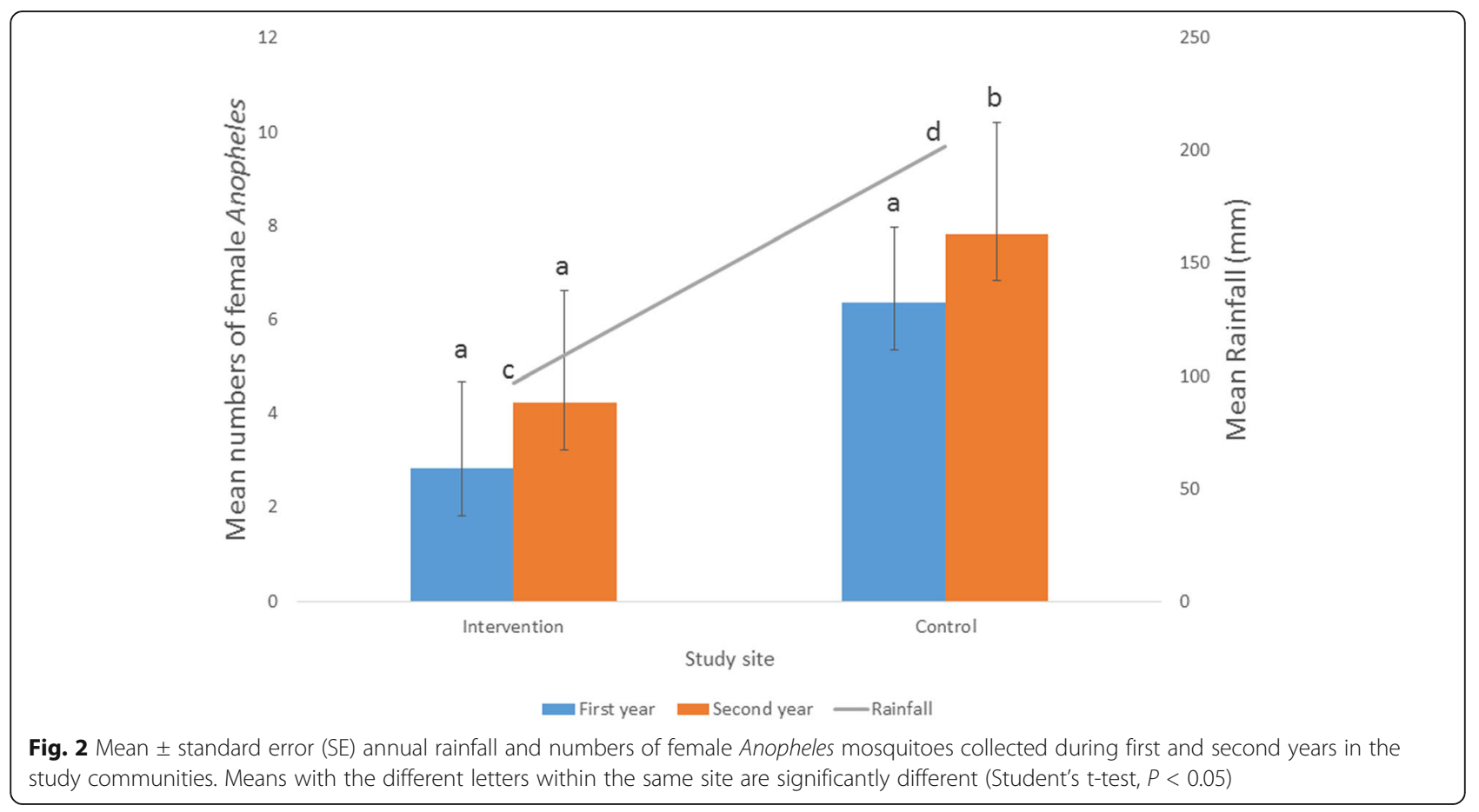

compared to second year. Mean man-biting rates of Anopheles mosquitoes increased significantly from first to second year in both intervention sites $(0.88 \pm 0.18 v s 1.06$ $\left.\pm 0.38 ; F_{(1,10)}=9.50, P=0.012\right)$ and control $(1.45 \pm 0.31$ vs $1.61 \pm 0.34 ; F_{(1,10)}=10.18, P=0.010$ ) (Table 3 ). Sporozoite rates increased from first to second year by at least

Table 3 Man-biting rates of female Anopheles mosquitoes in the study sites

\begin{tabular}{|c|c|c|c|c|c|c|c|c|}
\hline \multirow[t]{3}{*}{ Period } & \multicolumn{4}{|c|}{ Intervention site } & \multicolumn{4}{|c|}{ Control site } \\
\hline & \multicolumn{2}{|c|}{$\begin{array}{l}\text { Actual } \\
\text { values }\end{array}$} & \multicolumn{2}{|c|}{$\begin{array}{l}\text { Transformed } \\
\text { values }\end{array}$} & \multicolumn{2}{|c|}{$\begin{array}{l}\text { Actual } \\
\text { values }\end{array}$} & \multicolumn{2}{|c|}{$\begin{array}{l}\text { Transformed } \\
\text { values }\end{array}$} \\
\hline & $\begin{array}{l}\text { Year } \\
1\end{array}$ & $\begin{array}{l}\text { Year } \\
\|\end{array}$ & Year I & Year II & $\begin{array}{l}\text { Year } \\
1\end{array}$ & $\begin{array}{l}\text { Year } \\
\|\end{array}$ & Year I & Year II \\
\hline October & 0.21 & 1.99 & 0.84 & 1.58 & 1.38 & 2.96 & 1.37 & 1.86 \\
\hline November & 0.53 & 0.10 & 1.01 & 0.77 & 2.33 & 1.44 & 1.68 & 1.39 \\
\hline December & 0.03 & 0.00 & 0.73 & 0.71 & 1.50 & 2.01 & 1.41 & 1.58 \\
\hline January & 0.00 & 0.05 & 0.71 & 0.74 & 1.31 & 1.70 & 1.35 & 1.48 \\
\hline February & 0.00 & 0.00 & 0.71 & 0.71 & 1.34 & 1.49 & 1.36 & 1.41 \\
\hline March & 0.08 & 0.25 & 0.76 & 0.87 & 1.39 & 1.86 & 1.37 & 1.54 \\
\hline April & 0.71 & 1.57 & 1.10 & 1.44 & 1.88 & 3.30 & 1.54 & 1.95 \\
\hline May & 0.37 & 0.95 & 0.93 & 1.20 & 1.86 & 2.13 & 1.54 & 1.62 \\
\hline June & 0.25 & 0.28 & 0.87 & 0.88 & 0.81 & 0.78 & 1.14 & 1.13 \\
\hline July & 0.28 & 0.24 & 0.88 & 0.86 & 0.94 & 0.89 & 1.20 & 1.18 \\
\hline August & 0.04 & 0.84 & 0.73 & 1.16 & 0.86 & 2.73 & 1.17 & 1.79 \\
\hline September & 1.19 & 2.77 & 1.30 & 1.81 & 4.76 & 4.97 & 2.29 & 2.34 \\
\hline $\begin{array}{l}\text { Mean } \pm \\
\text { SD }\end{array}$ & & & $\begin{array}{l}0.88 \pm \\
0.18\end{array}$ & $\begin{array}{l}1.06 \pm \\
0.38\end{array}$ & & & $\begin{array}{l}1.45 \pm \\
0.31\end{array}$ & $\begin{array}{l}1.61 \pm \\
0.34\end{array}$ \\
\hline
\end{tabular}
to the first year in both intervention $(P=0.012)$ and control $(P=0.010)$ sites
1.6 times in intervention $(0-2.13 \%)$ and control $(2.56-$ 4.04\%) communities (Table 4). Only one An. coluzzii sample was found with $P$. falciparum sporozoites in the control community while all the infected mosquitoes recorded in the intervention village were identified as $A n$. gambiae.

\section{Insecticide resistance and mosquito susceptibility to installed DL}

Anopheles mosquito population from the intervention site were susceptible $(100 \%)$ at baseline but resistant (92\% mortality, see Additional file 3: Table S3) in the second year. However, $100 \%$ knockdown and mortality rates were recorded in the WHO cone susceptibility assay involving exposure of Anopheles population from the intervention site to subsamples of the installed DL all through the two-year period of the study.

Table 4 Sporozoite infection rates of endophilic Anopheles in the study sites

\begin{tabular}{|c|c|c|c|c|c|c|}
\hline \multirow[t]{2}{*}{ Study site } & \multirow[t]{2}{*}{ Year } & \multirow{2}{*}{$\begin{array}{l}\text { Total no. } \\
\text { of female } \\
\text { Anopheles }\end{array}$} & \multicolumn{3}{|c|}{$\begin{array}{l}\text { No. of Anopheles } \\
\text { positive for CSP }\end{array}$} & \multirow{2}{*}{$\begin{array}{l}\text { Sporozoite } \\
\text { rates of } \\
\text { mosquitoes } \\
\text { (\%) }\end{array}$} \\
\hline & & & $\begin{array}{l}\text { An. } \\
\text { gambiae }\end{array}$ & $\begin{array}{l}\text { An. } \\
\text { coluzzii }\end{array}$ & $\overline{\text { Total }}$ & \\
\hline \multirow[t]{2}{*}{ Intervention } & First & 128 & 0 & 0 & 0 & 0 \\
\hline & Second & 329 & 7 & 0 & 7 & 2.13 \\
\hline \multirow[t]{2}{*}{ Control } & First & 508 & 13 & 0 & 13 & 2.56 \\
\hline & Second & 792 & 31 & 1 & 32 & 4.04 \\
\hline
\end{tabular}


Table 5 Species composition of female Anopheles mosquito samples from the study sites

\begin{tabular}{|c|c|c|c|c|c|c|c|c|}
\hline \multirow[t]{2}{*}{ Period } & \multicolumn{4}{|c|}{ Intervention, $n(\%)$} & \multicolumn{4}{|l|}{ Control, n (\%) } \\
\hline & No. assayed & An. arabiensis & An. coluzzii & An. gambiae & No. assayed & An. arabiensis & An. coluzzii & An. gambiae \\
\hline First year & 97 & $0(0)$ & $15(15)$ & $82(85)$ & 311 & $2(0.6)$ & $79(25.4)$ & $230(74)$ \\
\hline Second year & 130 & $0(0)$ & $12(9.2)$ & $118(90.8)$ & 323 & $2(0.6)$ & $37(11.5)$ & $284(87.9)$ \\
\hline
\end{tabular}

\section{Anopheles species composition}

Anopheles gambiae was the predominant mosquito species in the intervention (85\% and 90.8\%) and control (74\% and $87.9 \%$ ) sites during the first and second years, respectively (Table 5). Only four An. arabiensis were identified in the two years of mosquito sampling in the control community.

\section{Discussion}

This study elucidates dynamics of malaria entomological indices in a community under DL installation in Kwara State, North Central Nigeria. Sustained insecticidal efficacy (100\% mortality) of installed DL could be due to reduced contact irritability [25] and higher insecticide dose uptake of the resistant mosquitoes [26] upon exposure to pyrethroidstreated surfaces. The continued efficacy of installed DL against resistant Anopheles population suggests that the increase in entomological indices (DL performance) in the second year of this study was not largely as a result of insecticide resistance or loss of DL efficacy. Rather, entomological indices increased with increase in rainfall from the first to the second year as evident also in the control community. This result agrees with the observation of continued efficacy of insecticide-treated materials (LLIN) after the development of resistance in the prevailing mosquitoes in the target community [26, 27]. Yet, it is important to maintain susceptibility of Anopheles mosquitoes to pyrethroids, the only class of insecticide currently approved for treating bednets [28]. Therefore, more efforts on development and assessments of non-pyrethroid DL is recommended for resistance management especially as insecticide resistance is currently becoming widespread and gaining potency in the An. gambiae mosquitoes [29, 30].

The significant correlation between rainfall and Anopheles densities could be linked to the availability of more rain-fed mosquito breeding sites during the rainy season period. Olayemi \& Ande [31] had earlier correlated rainfall with mean monthly mosquito abundance in Kwara State. Osse et al. [32] also reported higher human biting rate in second year compared to the first as a result of higher rainfall in some communities under IRS in Benin. However, the impact of DL installation in the intervention community was evident as significant $(P=$ $0.005)$ increase in rainfall did not translate to significant ( $P=0.067)$ increase in Anopheles densities from first to second year. An exception to the association between rainfall and Anopheles densities was found in the mid-rainy season (June-July) of both years when high rainfall and low numbers of Anopheles were recorded in both study sites. This is probably due to the high frequency of rainfall which often agitates and washes away the larval breeding sites. This observation has important implications in the event of scarce mosquito control resources expected to be targeted at the peak period of mosquito abundance.

Anopheles arabiensis absence and negligible occurrence in the intervention $(0 / 227)$ and control communities (4/634) is expected since the study area does not fall within the arid regions where this species is known to be abundant [19]. Anopheles man-biting rates increased significantly with rainfall despite mosquito density increase that was not significant in the intervention community from first to second year. This could be due to the strong anthropophagic tendencies of the prevailing $A n$. gambiae and An. coluzzii species in this village, as revealed by the high human blood indices of the mosquito samples. The result therefore shows the need for longitudinal DL evaluation over seasons and years to allow for additional recommendations such as the incorporation of larval management strategies especially in situations of high rainfall and Anopheles mosquito densities. This study is limited in that the findings may apply less under the recommended universal LLIN coverage community settings if and when it is sustainably achieved. Expected risks of transmission (EIR) could not be estimated due to pyrethrum spray collection method which collects indoor resting and not host-seeking mosquitoes.

\section{Conclusions}

This study reports on dynamics of malaria entomological indices within a community under deltamethrin durable wall lining installation in Akorede, Kwara State, Nigeria. The result showing no significant increase in Anopheles density within the intervention village, despite significant increase in rainfall and mosquito density within the neighbouring control village, suggests DL mortality effects as evidenced by $100 \%$ wild mosquito cone bioassays mortality results. However, the insignificant increase in Anopheles density was accompanied by increased sporozoite infection (0 to $2 \%$ ) and significantly increased man-biting rates within the intervention site. This shows the sensitivity of these indices to slight changes in vector density and therefore calls for the incorporation of integrated vector management strategies to complement DL installation 
especially in regions with abundant rainfall and high mosquito density. The use of non-pyrethroid DL will be worthwhile to restore and preserve vector susceptibility to pyrethroid insecticide currently being used for treatments of long-lasting insecticidal nets.

\section{Additional files}

Additional file 1: Table S1. Actual female Anopheles man-biting rate calculations in the intervention and control communities. (DOCX $18 \mathrm{~kb}$ )

Additional file 2: Table S2. Human blood indices of female Anopheles mosquitoes in the intervention and control communities. (DOCX $17 \mathrm{~kb}$ )

Additional file 3: Table S3. Insecticide susceptibility results. Number of dead/alive mosquitoes at the end of holding period (24 h). (DOCX $13 \mathrm{~kb}$ )

\section{Abbreviations}

ELISA: enzyme-linked immunosorbent assay; PCR: polymerase chain reaction; DL: insecticide-treated durable wall lining; ITPS: insecticide-treated plastic sheeting; HDPE: high density polyethylene; IRS: indoor residual spray; LLIN: long-lasting insecticidal net; EIR: entomological inoculation rate; NPC: National Population Commission; NIMET: Nigerian Meteorological Agency; RFLP: restriction fragment length polymorphism; SPSS: Statistical Package for the Social Sciences; NIMR: Nigerian Institute of Medical Research; NMEP: National Malaria Elimination Program; WHO: World Health

Organization; CSP: circumsporozoite protein

\section{Acknowledgements}

The authors appreciate the staff of the Molecular Entomology and Vector Control Research Laboratory at the Nigerian Institute of Medical Research for their efforts during the laboratory analysis. The officials of Kwara State Roll Back Malaria Office are gratefully acknowledged for their support during the social advocacy visits to the communities.

\section{Funding}

This study was funded by Vestergaard Frandsen but the funders had no role in data analysis, interpretation of the results, decision to publish or preparation of this manuscript. The findings described here are those of the authors and do not necessarily reflect views of Vestergaard Frandsen.

\section{Availability of data and materials}

The datasets supporting conclusions of this article are presented within the article and its additional files.

\section{Authors' contributions}

TSA, AOO and KOKP conceived and designed the study. AO and AOO coordinated the field and laboratory studies. AO collated, analyzed the data and drafted the manuscript. All authors read and approved the final manuscript.

\section{Ethics approval and consent to participate}

The study was approved by the Ethical Review Board of The Nigerian Institute of Medical Research (NIMR) under the Nigerian Institute of Medical Research /National Malaria Elimination Programme (NMEP) project. Written informed consent of household heads was obtained during social advocacy visits to the communities in the company of the officials of the Kwara State Roll Back Malaria Office.

\section{Consent for publication}

Not applicable.

\section{Competing interests}

The authors declare that they have no competing interests.

\section{Publisher's Note}

Springer Nature remains neutral with regard to jurisdictional claims in published maps and institutional affiliations.

\section{Author details}

'Department of Biosciences and Biotechnology, Kwara State University Malete, Malete, Nigeria. ${ }^{2}$ Department of Zoology, University of Ibadan, Ibadan, Nigeria. ${ }^{3}$ Molecular Entomology and Vector Control Research Laboratory, Nigerian Institute of Medical Research, Yaba, Lagos, Nigeria. ${ }^{4}$ Department of Zoology, University of Ilorin, Ilorin, Nigeria.

Received: 30 May 2018 Accepted: 27 August 2018

Published online: 04 September 2018

\section{References}

1. Yé Y, Louis VR, Simboro S, Sauerborn R. Effect of meteorological factors on clinical malaria risk among children: an assessment using village-based meteorological stations and community-based parasitological survey. BMC Public Health. 2007;7:101.

2. Paaijmans KP, Read AF, Thomas MB. Understanding the link between malaria risk and climate. Proc Natl Acad Sci USA. 2009;106:13844-9.

3. Charlwood JD, Kihonda J, Sama S, Billingsley PF, Hadji H, Verhave JP, et al. The rise and fall of Anopheles arabiensis (Diptera: Culicidae) in a Tanzanian village. Bull Entomol Res. 1995;85:37-44.

4. Shaukat AM, Breman JG, Mckenzie FE. Using the entomological inoculation rate to assess the impact of vector control on malaria parasite transmission and elimination. Malar J. 2010;9:122

5. Messenger LA, Miller NP, Adeogun AO, Awolola TS, Rowland M. The development of insecticide-treated durable wall lining for malaria control: insights from rural and urban populations in Angola and Nigeria. Malar J. 2012;11:332.

6. Messenger LA, Matias A, Manana AN, Stiles-Ocran JB, Knowles S, Boakye DA, et al. Multicentre studies of insecticide-treated durable wall lining in Africa and Southeast Asia: entomological efficacy and household acceptability during one year of field use. Malar J. 2012;11:358.

7. Sharma SK, Upadhyay AK, Haque MA, Tyagi PK, Mohanty SS, Mittal PK, et al. Field evaluation of ZeroFlyW - an insecticide incorporated plastic sheeting against malaria vectors and its impact on malaria transmission in tribal areas of northern Orissa. Indian J Med Res. 2009:130:458-66.

8. Burns M, Rowland M, N'Guessan R, Carneiro I, Beeche A, Ruiz SS, et al. Insecticide-treated plastic sheeting for emergency malaria prevention and shelter among displaced populations: an observational cohort study in a refugee setting in Sierra Leone. Am J Trop Med Hyg. 2012:87:242-50.

9. Mittal PK, Sreehari U, Razdan RK, Dash AP. Evaluation of the impact of ZeroFlyW, an insecticide incorporated plastic sheeting on malaria incidence in two temporary labour shelters in India. J Vector Borne Dis. 2011;48:138-43.

10. Oduola AO, Adelaja OJ, Aiyegbusi ZO, Monday T, Obembe A, Ande AT, et al. Dynamics of Anopheline vector species composition and reported malaria cases during the rain and dry season in two selected communities in Kwara state. Nigerian J Parasitol. 2016:37:158-64.

11. National Population Commission. State Population; 2016. http://www. population.gov.ng.

12. Nigerian Meteorological Agency. Monthly weather review. Abuja: National Weather Forecasting and Climate Research Centre, Nnamdi Azikwe International Airport; 2014. http://www.nimet.gov.ng

13. Amek N, Bayoh N, Hamel M, Lindblade KA, Gimnig JE, Odhiambo F, et al. Spatial and temporal dynamics of malaria transmission in rural western Kenya. Parasit Vectors. 2012;5:86.

14. World Health Organization. Test procedures for insecticide resistance in malaria vectors, bio-efficacy and persistence of insecticides on treated surfaces. WHO/ CDS/CPC/MAL/98, vol. 12. Geneva: World Health Organization; 1998.

15. World Health Organization. Guidelines for testing mosquito adulticides for indoor residual spraying and mosquito net treatment WHO_CDS_NTD_ WHOPES_GCDPP_2006. Geneva: World Health Organization; 2006.

16. World Health Organization. Malaria entomology and vector control: Learner's guide. Geneva: World Health Organization; 2003. http://whqlibdoc. who.int/hq/2003/WHO-_CDS_CPE_SMT_2002.18_Rev.1_Partl.pdf.

17. Shililu JI, Maier WA, Seitz HM, Orago AS. Seasonal density, sporozoite rates and entomological inoculation rates of Anopheles gambiae and Anopheles funestus in a high-altitude sugarcane growing zone in western Kenya. Trop Med Intl Health. 1998:3:706-10.

18. Mbogo CM, Mwangangi JM, Nzovu J, Gu W, Yan G, Gunter J, et al. Spatial and temporal heterogeneity of Anopheles mosquitoes and Plasmodium falciparum transmission along the Kenyan coast. Am J Trop Med Hyg. 2003;68:734-42. 
19. Gillies MT, Coetzee MA. Supplement to the Anophelinae of Africa South of the Sahara (Afrotropical region). Pub South Afri Inst Med Res. 1987;55:141-3.

20. Scott JA, Brogdon WG, Collins FH. Identification of single specimens of the Anopheles gambiae complex by the polymerase chain reaction. Am J Trop Med Hyg. 1993;49:520-9.

21. Favia G, della Torre A, Bagayoko M, Lanfrancotti A, Sagnon N, Toure YT, et al. Molecular identification of sympatric chromosomal forms of Anopheles gambiae and further evidence of their reproductive isolation. Insect Mol Biol. 1997;6:377-83.

22. Wirtz RA, Zavala F, Charoenvit Y, Cambell GH, Burkot TR, Schneider I, et al. Comparative testing of Plasmodium falciparum sporozoite monoclonal antibodies for ELISA development. Bull World Health Org. 1987;65:39-45.

23. Beier JC, Perkins PV, Wirtz RA, Oros J, Diggs D, Gargan TP, et al. Blood meal identification by direct enzyme-linked Immunosorbent assay (ELISA), tested on Anopheles (Diptera: Culicidae) in Kenya. J Med Entomol. 1988:25:9-16.

24. Ogbeigbu AE. Biostatistics: A practical approach to research and data handling. Benin City: Mindex Publishing Company Limited; 2005.

25. Chandre F, Darriet F, Duchon S, Finot L, Manguin S, Carnevale P, et al. Modifications of pyrethroid effects associated with $k d r$ mutation in Anopheles gambiae. Med Vet Entomol. 2000;14:81-8.

26. Henry M, Assi S, Rogier C, Dossou-yovo J, Chandre F, Guillet P, et al. Protective efficacy of lambda-cyhalothrin treated nets in Anopheles gambiae pyrethroid resitance areas of Côte d'Ivoire. Am J Trop Med Hyg. 2005;73:859-64.

27. Dabiré RK, Diabaté A, Baldet T, Paré-Toé L, Guiguemdé RT, Ouédraogo J, et al. Personal protection of long lasting insecticide-treated nets in areas of Anopheles gambiae s.s. resistance to pyrethroids. Malar J. 2006:5:12

28. Zaim M, Aitio A, Nakashima N. Safety of pyrethroid-treated mosquito net. Med Vet Entomol. 2000;14:1-5.

29. Strode C, Donegan S, Garner P, Enayati AA, Hemingway J. The impact of pyrethroid resistance on the efficacy of insecticide-treated bed nets against African anopheline mosquitoes: systematic review and meta-analysis. PLoS Med. 2014;11:e1001619.

30. Toé KH, Jones $\mathrm{CM}$, N'Fale $\mathrm{S}$, Ismail HM, Dabiré RK, Ranson $\mathrm{H}$. Increased pyrethroid resistance in malaria vectors and decreased bed net effectiveness in Burkina Faso. Emerg Infect Dis. 2014:20:1691-6.

31. Olayemi IK, Ande AT. Species diversity and temporal dynamics of Anopheles mosquito (Diptera: Culicidae) in Ilorin. Nigeria. Africa J Biosci. 2008;1:84-8.

32. Osse RA, Aikpon R, Gbedjissi GL, Gnanguenon V, Sezonlin M, Govoetchan R, et al. A shift from indoor residual spraying (IRS) bendiocarb to long-lasting insecticidal (mosquito) nets (LLINs) associated with changes in malaria transmission indicators in pyrethroid resistance areas in Benin. Parasit Vectors. 2013;6:73.

Ready to submit your research? Choose BMC and benefit from:

- fast, convenient online submission

- thorough peer review by experienced researchers in your field

- rapid publication on acceptance

- support for research data, including large and complex data types

- gold Open Access which fosters wider collaboration and increased citations

- maximum visibility for your research: over $100 \mathrm{M}$ website views per year

At $\mathrm{BMC}$, research is always in progress.

Learn more biomedcentral.com/submissions 